\title{
Substance Use Sequence Number
}

National Cancer Institute

\section{Source}

National Cancer Institute. Substance Use Sequence Number. NCI Thesaurus. Code C83428.

An identifier that describes the relative position of substance use data within a series. 